\title{
OPERASI TANGKAP TANGAN DALAM PENANGANAN KASUS KORUPSI HAND ARREST OPERATION IN HANDLING CORRUPTION CASE
}

\author{
Puteri Hikmawati \\ Pusat Penelitian Badan Keahlian DPR RI \\ Komplek MPR/DPR/DPD Gedung Nusantara 1 Lantai 2, \\ Jl. Jenderal Gatot Subroto Jakarta \\ Email: puteri.hikmawati@dpr.go.id \\ Naskah diterima: 27 Maret 2018 \\ Naskah direvisi: 18 Mei 2018 \\ Naskah diterbitkan: 30 Juni 2018
}

\begin{abstract}
Hand arrest operation (OTT) is one of the efforts conducted in handling the corruption cases. Since 2005 until 2017 The Corruption Eradication Commission (KPK) has conducted approximately 77 OTT. In addition to KPK, the Government established a Sweeping Illegal Levies Task Force (Satgas Saber Pungli) through the Presidential Regulation No. 87 year 2016, which also conducted OTT related to illegal levies. However, the term OTT is not mentioned on the legal provisions of the corruption case handling procedures. The provisions on the procedural law only regulated the arrest and hand arrest. Therefore, the legal issue in this paper is whether the implementation of OTT by KPK and Satgas Saber Pungli are in accordance with the criminal law procedure. This paper are the result of juridical normative and juridical empirical research, using a qualitative approach. In the study described that the implementation of OTT by the KPK, which preceded by the wiretapping, meanwhile the tapping mechanism and procedures not have been regulated in an Act, as mandated by the Constitutional Court Decision. While OTT conducted by Satgas Saber Pungli based on report of the society. Based on the research, OTT conducted by KPK and Saber Pungli Task Force, in this case the Police and Attomey General, are not violated the criminal law procedure. However, for the authorithies harmonization the wiretapping authority should be given to the Police and the Prosecutor's Office whose handling the corruption cases, and the requirement hand arrest in the Criminal Procedure Code must be clarified on the criteria and requirements, so that its implementation does not depend on the interpretation of the instrument of the institution.
\end{abstract}

Key words: hand arrest operation; corruption; the corruption eradication commission; sweeping illegal levies task force; criminal law procedure

\begin{abstract}
Abstrak
Operasi tangkap tangan (OTT) merupakan salah satu upaya yang dilakukan dalam penanganan kasus korupsi. Sejak tahun 2005 sampai dengan 2017, KPK telah melakukan sebanyak 77 OTT. Selain KPK, Pemerintah membentuk Satuan Tugas Sapu Bersih Pungli (Satgas Saber Pungli) dengan Peraturan Presiden No. 87 Tahun 2016, yang juga melakukan OTT berkaitan dengan pungutan liar. Namun, istilah OTT tidak terdapat dalam ketentuan hukum acara penanganan kasus korupsi. Ketentuan hukum acara hanya mengatur penangkapan dan tertangkap tangan. Oleh karena itu, permasalahan hukum dalam tulisan ini adalah apakah pelaksanaan OTT oleh KPK dan Satgas Saber Pungli telah sesuai dengan hukum acara pidana. Tulisan ini merupakan hasil penelitian yuridis normatif dan yuridis empiris, dengan menggunakan pendekatan kualitatif. Dalam pembahasan diuraikan pelaksanaan OTT oleh KPK, yang didahului dengan penyadapan, sementara mekanisme dan prosedur penyadapan harus diatur dalam UU, sebagaimana amanat Putusan Mahkamah Konstitusi. Sedangkan OTT yang dilakukan oleh Satgas Saber Pungli berdasarkan laporan dari masyarakat. Berdasarkan hasil penelitian, OTT yang dilakukan oleh KPK dan Satgas Saber Pungli, dalam hal ini Kepolisian dan Kejaksaan, tidak menyalahi hukum
\end{abstract}


acara pidana. Namun, untuk harmonisasi, kewenangan penyadapan perlu diberikan kepada Kepolisian dan Kejaksaan yang menangani kasus korupsi, dan persyaratan tertangkap tangan dalam KUHAP harus dipertegas kriteria dan syaratnya, agar pelaksanaannya tidak tergantung pada penafsiran aparat.

Kata kunci: operasi tangkap tangan; korupsi; KPK; Saber Pungli; hukum acara pidana

\section{PENDAHULUAN}

Saat ini modus korupsi yang dilakukan oleh pelaku semakin canggih. Perkembangan teknologi dan globalisasi menjadi salah satu pemicu tumbuhnya sarana baru dalam menyimpan aset atau harta hasil kejahatan. Modus-modus yang tidak konvensional, antara lain seperti yang dilakukan oleh Wali Kota Cilegon Tubagus Iman Ariyadi yang menyamarkan suap melalui donatur dana tanggung jawab sosial perusahaan untuk sebuah klub sepak bola. Ada pula penggunaan kartu anjungan tunai mandiri dengan nama fiktif. Uang tidak lagi diberikan secara tunai. Hal ini terungkap dalam dugaan suap terhadap Direktur Jenderal Perhubungan Laut Antonius Tonny Budiono. Yang terbaru terjadi pada korupsi pengadaan KTP elektronik yang memakai transaksi lintas negara dengan kombinasi layanan money changer. ${ }^{1}$

Penegak hukum harus mengikuti perkembangan cara berpikir orang dalam menyimpan aset atau kekayaannya. Dalam teknologi internet, orang dapat menyimpan harta dalam bentuk mata uang virtual seperti bitcoin. Tidak tertutup kemungkinan di masa depan akan ditemui korupsi dengan menyembunyikan atau mencuci harta melalui mata uang virtual yang belum pernah dikenal sebelumnya. Oleh karena itu, penyidik kasus korupsi didorong untuk mengikuti perkembangan terbaru sarana penyimpanan aset dan kekayaan, tidak terbatas pada bentuk tunai dan tabungan, tetapi juga saham, valuta asing, dan/atau uang virtual.

“Modus Kian Canggih”, Kompas, 20 Januari 2018.
Semakin canggihnya modus korupsi yang dilakukan oleh pelaku menjadi masalah serius bagi bangsa Indonesia. Saat ini penyidikan kasus korupsi dilakukan oleh Kepolisian, Kejaksaan, dan Komisi Pemberantasan Tindak Pidana Korupsi (KPK). Dasar hukum Kejaksaan dalam menangani tindak pidana korupsi (tipikor) adalah Pasal 284 ayat (2) UU No. 8 Tahun 1981 tentang Hukum Acara Pidana (KUHAP) jo. Pasal 17 Peraturan Pemerintah No. 27 Tahun 1983 tentang Pelaksanaan Kitab Undang-Undang Hukum Acara Pidana, dan wewenang Kepolisian dalam penyidikan tipikor didasarkan pada Pasal 1 angka 1 dan Pasal 6 ayat (1) KUHAP serta Pasal 26 Undang-Undang (UU) No. 31 Tahun 1999 tentang Pemberantasan Tindak Pidana Korupsi sebagaimana telah diubah dengan UU No. 20 Tahun 2001 tentang Perubahan atas UU No. 31 Tahun 1999 tentang Pemberantasan Tindak Pidana Korupsi (UU Tipikor).

Sementara itu, KPK merupakan lembaga negara yang pembentukannya diamanatkan oleh Pasal 43 UU Tipikor. Adapun dasar pertimbangan dibentuknya KPK, bahwa pemberantasan tindak pidana korupsi belum dapat dilaksanakan secara optimal dan lembaga pemerintah yang menangani perkara tindak pidana korupsi belum berfungsi secara efektif dan efisien dalam memberantas tindak pidana korupsi. Selanjutnya, KPK secara khusus dibentuk dengan UU No. 30 Tahun 2002 tentang Komisi Pemberantasan Tindak Pidana Korupsi (UU KPK), dengan tujuan meningkatkan daya guna dan hasil guna terhadap upaya pemberantasan tipikor.

Pemberantasan korupsi dilakukan oleh KPK secara intensif karena memang menjadi tugas KPK melakukan penyelidikan, penyidikan, dan penuntutan tindak pidana korupsi. Salah satu upaya yang dilakukan oleh KPK dalam menangani kasus korupsi adalah dengan operasi tangkap tangan (OTT). Sejak tahun 2005 sampai dengan 2017 KPK telah melakukan sebanyak 77 OTT, dengan rincian sebagai berikut. ${ }^{2}$

\footnotetext{
"Pencalonan Tidak Berdasarkan Integritas", Suara Pembaruan, 27 Desember 2017, dan "Pemberantasan Korupsi 2017: Jumlah OTT Meningkat”, Suara Pembaruan, 28 Desember 2017.
} 
Tabel 1. OTT yang Dilakukan oleh KPK 2005 - 2017

\begin{tabular}{cccccccccccccc}
\hline Tahun & 2005 & 2006 & 2007 & 2008 & 2009 & 2010 & 2011 & 2012 & 2013 & 2014 & 2015 & 2016 & 2017 \\
\hline $\begin{array}{c}\text { Jumlah } \\
\text { OTT }\end{array}$ & 3 & - & 1 & 4 & 1 & 2 & 6 & 4 & 10 & 5 & 5 & 17 & 19 \\
\hline
\end{tabular}

Sumber: Laporan Tahunan KPK Tahun 2016 dan Capaian dan Kinerja KPK di Tahun 2017

Berdasarkan Tabel 1, terdapat 19 kasus yang merupakan hasil tangkap tangan (OTT) pada tahun 2017. Jumlah kasus tangkap tangan di tahun 2017 ini telah melampaui tahun sebelumnya dan merupakan terbanyak sepanjang sejarah KPK berdiri. Dari 19 kasus tersebut, KPK telah menetapkan 72 orang sebagai tersangka dengan beragam profil tersangka, mulai dari aparat penegak hukum, anggota legislatif hingga kepala daerah. Jumlah tersebut belum termasuk tersangka yang ditetapkan kemudian dari hasil pengembangan perkara. $^{3}$ Sebelumnya, pada tahun 2016 OTT terbanyak dilakukan oleh KPK sebanyak 17 OTT. Dari OTT tersebut, KPK menetapkan sebanyak 56 tersangka. Para tersangka itu berasal dari berbagai profesi, mulai dari aparat penegak hukum, anggota legislatif, hingga kepala daerah. Jumlah tersebut belum termasuk tersangka yang ditetapkan dari hasil pengembangan perkara. ${ }^{4}$

Beberapa pejabat telah terkena OTT dalam dugaan kasus korupsi, antara lain Irman Gusman (Ketua Dewan Perwakilan Daerah), yang diduga menerima suap Rp100.000.000,00 (seratus juta rupiah) dari Xaveriandy dan Memi (Pengusaha) sebagai imbalan atas jasa Irman dalam mengupayakan keduanya mendapat jatah pembelian gula impor di Bulog sebesar 1.000 ton $^{5}$; Akil Mochtar (Ketua Mahkamah Konstitusi) yang diduga menerima suap untuk dua kasus sengketa Pilkada Kabupaten Gunung

“Capaian dan Kinerja KPK di Tahun 2017”, Siaran Pers disampaikan oleh Pimpinan KPK, 27 Desember 2017, http://www.poetramerdeka.com/2017/12/siaran-pers-kpkcapaian-dan-kinerja-di.html, diakses tanggal 12 Mei 2018. "KPK: 17 OTT di 2016 Terbanyak Sepanjang Sejarah", 9 Januari 2017, https://news.detik.com/berita/d-3391210/ kpk-17-ott-di-2016-terbanyak-sepanjang-sejarah, diakses tanggal 12 Mei 2018.

"Penyelidik KPK Ungkap Cerita OTT Irman Gusman", 4 Januari 2017, https://news.detik.com/berita/d-3387547/ penyelidik-kpk-ungkap-cerita-ott-irman-gusman, diakses tanggal 20 Februari 2017.
Mas, Kalimantan Tengah, dan Lebak, Banten ${ }^{6}$; Patrialis Akbar (Hakim Konstitusi) yang diduga menerima suap ratusan ribu dolar dari Basuki Hariman untuk perkara Uji Materi UU No. 41 Tahun 2014 tentang Peternakan dan Kesehatan Hewan; ${ }^{7}$ serta pada akhir tahun 2017 KPK melakukan OTT dan menetapkan empat orang tersangka dalam kasus dugaan suap pengesahan Rancangan APBD tahun 2018 Provinsi Jambi. Keempat tersangka tersebut yakni Plt. Sekda Jambi Erwan Malik, Asisten III Pemprov Jambi Saifuddin, Plt. Kepala Dinas PU Arfan dan anggota DPRD Jambi Supriono. Dari hasil pengembangan perkara korupsi tersebut KPK menetapkan Gubernur Jambi Zumi Zola sebagai tersangka, karena diduga menerima hadiah atau janji sebesar Rp. 6 miliar dari sejumlah proyek yang ada di Provinsi Jambi. ${ }^{8}$

Selain KPK, penyidik Kepolisian Negara Republik Indonesia (Polri) juga melakukan OTT di Kementerian Perhubungan (Kemenhub), 11 Oktober 2016, berkaitan dengan pungutan liar (pungli) di sektor pelayanan pelayaran laut. Terkait OTT tersebut, penelusuran terhadap pungli sudah dilakukan oleh Polri sejak pertengahan 2016. Dalam OTT di tempat perizinan ditemukan uang Rp61 juta dan Rp1 miliar lebih. ${ }^{9}$

\footnotetext{
6 "Kronologis Penangkapan Akil Mochtar", 3 Oktober 2013, http://www.republika.co.id/berita/nasional/hukum/ 13/10/03/mu3hdy-kronologis-penangkapan-akil-mochtar, diakses tanggal 20 Februari 2017.

"KPK: Penyuap Patrialis Pernah Diperiksa Kasus Impor Daging Sapi”, 27 Januari 2017, http://news.liputan6.com/ $\mathrm{read} / 2838364 / \mathrm{kpk}$-penyuap-patrialis-pernah-diperiksakasus-impor-daging-sapi, diakses tanggal 20 Februari 2017. "Ini Daftar Lengkap 19 OTT KPK Sepanjang 2017", 2 Januari 2018, http://nasional.republika.co.id/berita/nasional/ hukum/18/01/01/p1vv1h409-ini-daftar-lengkap-19-ott-kpksepanjang-2017, diakses tanggal 22 Maret 2018.

“Tertangkap Tangan Pertama Polisi dan Kekhawatiran Pencitraan", 12 Oktober 2016, http://www.cnnindonesia. com/nasional/20161012090723-12-164914/tangkaptangan-pertama-polisi-dan-kekhawatiran-pencitraan/, diakses tanggal 10 Maret 2017.
} 
OTT pungli bukan merupakan hal yang baru di Kepolisian. Wakil Kepala Polisi Daerah Metro Jaya, Brigjen Pol. Suntana, mengatakan bahwa di internal Polda Metro Jaya memang tengah dilakukan pemberantasan pungli. Namun, OTT pungli itu telah dilakukan sejak lama. ${ }^{10}$ Satuan Tugas (Satgas) Saber Pungli Pusat dan Daerah melakukan OTT sebanyak 71 kali selama 2016. Lima OTT di antaranya terjadi di DKI Jakarta. ${ }^{11}$

Istilah OTT tidak terdapat dalam ketentuan hukum acara penanganan kasus korupsi. KUHAP, UU KPK, dan UU Tipikor tidak mengatur OTT, tetapi mengatur penangkapan. KUHAP mengatur penangkapan karena penangkapan dan upaya paksa lainnya seperti penahanan dan penggeledahan menyangkut hak dasar atau hak asasi manusia yang berdampak tidak hanya bagi kehidupan yang bersangkutan, tetapi juga keluarganya.

Ada dua macam penangkapan, yakni tertangkap tangan dan tidak dalam keadaan tertangkap tangan. Tertangkap tangan berbeda dengan OTT. Menurut Laica Marzuki, Pengajar Universitas Hasanuddin, Makassar, OTT tidak dikenal dalam KUHAP. OTT tidak dapat didahului dengan serangkaian kegiatan penelitian. Jika didahului penelitian, sedianya disebut penangkapan. Ketika upaya penangkapan, syaratnya ada surat tugas dan surat perintah penangkapan, yang menjelaskan identitas dan alasan-alasan penangkapan. OTT adalah istilah yang mengandung makna kontradiksi atau berlawanan, dan mengacaukan istilah hukum. ${ }^{12}$ Menurut Fahri Hamzah,

10 "Polda Metro Jaya: OTT Pungli Bukan Hal Baru di Kepolisian”, 18 Oktober 2016, http://metro.news.viva.co.id/ news/read/836194-polda-metro-jaya-ott-pungli-bukan-halbaru-di-kepolisian, diakses tanggal 2 Maret 2017.

11 "Satgas Saber Pungli Lakukan 71 OTT Sepanjang 2016", 6 Januari 2017, http://news.liputan6.com/read/2820153/ tim-satgas-saber-pungli-lakukan-71-ott-sepanjang-2016, diakses tanggal 2 Maret 2017.

12 Penjelasan Laica Marzuki sebagai Ahli, yang disampaikan di hadapan hakim tunggal I Wayan Karya dalam Sidang Praperadilan Irman Gusman melawan KPK di Pengadilan Negeri Jakarta Selatan, 27 Oktober 2016, Harian Haluan, 2 Februari 2017, "Laica Marzuki Jadi Saksi Ahli IG", 28 Oktober 2016, http:/harianhaluan.com/news/detail/61394/istilah-ottkacaukan-hukum-acara, diakses tanggal 2 Februari 2017. pelaksanaan OTT tidak menyentuh persoalan dalam menuntaskan korupsi di Indonesia. ${ }^{13}$

Demikian pula menurut Hibnu Nugroho, Guru Besar Universitas Jenderal Soedirman, Poerwokerto, OTT adalah istilah yang tidak tepat dan tidak diatur dalam KUHAP. Yang tepat adalah operasi penangkapan karena sebelumnya sudah didahului dan ditemukan bukti permulaan yang cukup. Dalam ilmu kriminalistik, tindakan tersebut merupakan bagian dari taktik pengungkapan kejahatan oleh penyidik. ${ }^{14}$

Berdasarkan uraian tersebut, maka pelaksanaan OTT patut dipermasalahkan, agar tidak terjadi perampasan kemerdekaan orang secara sewenang-wenang. Adapun permasalahan pokok dalam penelitian ini adalah apakah pelaksanaan OTT oleh KPK dan Satgas Saber Pungli telah sesuai dengan Hukum Acara Pidana? Berdasarkan permasalahan tersebut, beberapa pertanyaan penelitian yang diajukan adalah:

1. Apa dasar hukum OTT?

2. Bagaimana pelaksanaan OTT oleh KPK dan Satgas Saber Pungli serta perbandingannya?

Penelitian ini penting dilakukan karena akhir-akhir ini OTT sering dilakukan oleh KPK dan Satgas Saber Pungli, dengan jenis kasus yang berbeda. KPK melakukan OTT atas dugaan suap yang dilakukan oleh pejabat negara, sementara Kepolisian melakukan OTT terhadap pungli yang dilakukan oleh petugas. Sementara itu, Kejaksaan yang juga mempunyai tugas melakukan penyidikan tindak pidana korupsi tidak melakukan OTT dalam penanganan kasus korupsi. Bahkan Jaksa Agung HM Prasetyo menilai praktik pemberantasan korupsi melalui OTT kerap

Fahri Hamzah, "Sistematika Pemberantasan Korupsi", Makalah disampaikan dalam acara Seminar Nasional dengan tema "Pemetaan Korupsi di Lembaga Eksekutif, Legislatif, dan Yudikatif: Strategi Pencegahan dan Penindakannya", diselenggarakan oleh Pusat Penelitian Badan Keahlian DPR RI, 30 Maret 2017, hal. 1-6.

14 "Memahami Istilah Operasi Tangkap Tangan di Kasus Patrialis Akbar", 30 Januari 2017, https://news.detik.com/ berita/d-3409476/memahami-istilah-operasi-tangkaptangan-di-kasus-patrialis-akbar, diakses tanggal 20 Februari 2017. 
menimbulkan kegaduhan dan tidak mampu meningkatkan indeks persepsi korupsi (IPK) Indonesia. ${ }^{15}$

Berdasarkan penelusuran, beberapa tulisan terkait OTT sebagai berikut:

1. "Kebijakan KPK dalam Penanggulangan Tindak Pidana Korupsi melalui Operasi Tangkap Tangan", yang ditulis oleh Muhammad Rizal Akbar, merupakan penelitian skripsi dari Fakultas Hukum Universitas Lampung, 2016. Permasalahan dalam tulisan ini adalah bagaimana kebijakan KPK dalam penanggulangan tindak pidana korupsi melalui OTT, dan apa faktor penghambatnya. ${ }^{16}$ Penelitian ini fokus pada kebijakan dan faktor penghambat KPK dalam penanggulangan tindak pidana korupsi melalui OTT.

2. "Analisa Yuridis terhadap Tindakan Tangkap Tangan Terhadap Pelaku Dugaan Tindak Pidana Gratifikasi”, merupakan laporan penelitian yang ditulis oleh Bambang Tri Bawono, Fakultas Hukum Universitas Islam Sultan Agung, Semarang, 2013. Pokok masalah dalam tulisan ini adalah bagaimana pandangan hukum terhadap tindakan tangkap tangan terhadap pelaku dugaan tindak pidana gratifikasi dan akibat hukum terhadap tindakan tangkap tangan terhadap pelaku dugaan tindak pidana gratifikasi. ${ }^{17}$ Penelitian ini secara khusus mempermasalahkan OTT yang dilakukan terhadap pelaku tindak pidana gratifikasi.

3. "Primordialisme Semu Versus Gerakan Antikorupsi (Studi Kritis Pemberitaan Tangkap tangan Irman Gusman di Media Daring Sumatera Barat dan Nasional)",

15 "Menurut Jaksa Agung, OTT Kerap Bikin Gaduh", 11 September 2017, https://nasional.kompas.com/ $\mathrm{read} / 2017 / 09 / 11 / 15551721 /$ menurut-jaksa-agung-ottkerap-bikin-gaduh, diakses tanggal 13 Maret 2018.

16 Muhammad Rizal Akbar, "Kebijakan KPK dalam Penanggulangan Tindak Pidana Korupsi melalui Operasi Tangkap Tangan", Jurnal Skripsi, Fakultas Hukum Universitas Lampung, 2016, hal. 1-13.

17 Bambang Tri Bawono, "Analisa Yuridis terhadap Tindakan Tangkap Tangan Terhadap Pelaku Dugaan Tindak Pidana Gratifikasi”, Laporan Penelitian, Fakultas Hukum Universitas Islam Sultan Agung, Semarang, 2013. ditulis oleh Mohammad Isa Gautama. ${ }^{18}$ Penelitian ini menganalisis bagaimana media dalam jaringan (online media) menampilkan dan mengemas serta mengkonstruksi berita langsung (straight news) tentang OTT yang dilakukan oleh KPK terhadap Ketua DPD Periode 2014-2019, Irman Gusman, pada 17 September 2016.

4. "Analisis Framing Berita Penangkapan Gubernur Riau Annas Maamun di Surat Kabar Riau Pos dan Tribun Pekanbaru", ditulis oleh Al Sukri, Chelsy Yesicha, dalam Jurnal Komunikasi Global. ${ }^{19}$ Tulisan ini menganalisis konstruksi pemberitaan penangkapan Gubernur Riau Annas Maamun pada Surat Kabar Riau Pos dan Surat Kabar Tribun Pekanbaru; dan ideologi media yang diterapkan pada Surat Kabar Riau Pos dan Surat Kabar Tribun Pekanbaru terkait kasus penangkapan Gubernur Riau Annas Maamun.

5. "Optimalisasi Pemberantasan Korupsi dalam Era Desentralisasi di Indonesia", ditulis oleh Suharyo, dalam Jurnal Rechtsvinding. ${ }^{20}$ Permasalahan yang diangkat dalam tulisan ini mengenai faktor yang menyebabkan perilaku korupsi pada era desentralisasi dan optimalisasi pemberantasan korupsi di tengah desentralisasi.

Artikel no. 1, 2, dan 5 merupakan tulisan terkait ilmu hukum yang ditulis dengan metode yuridis normatif dengan pendekatan kepustakaan. Sedangkan artikel no. 3 dan 4 merupakan tulisan yang tidak terkait ilmu hukum, tetapi menganalisis peran media dalam menampilkan berita OTT yang dilakukan terhadap seorang pejabat atau penyelenggara negara.

\footnotetext{
Mohammad Isa Gautama, "Primordialisme Semu Versus Gerakan Antikorupsi (Studi Kritis Pemberitaan Tangkap tangan Irman Gusman di Media Daring Sumatera Barat dan Nasional)", Prosiding Magister Ilmu Komunikasi, Jurnal FISIP Unila, 2017, hal. 1-14.

19 Al Sukri dan Chelsy Yesicha, "Analisis Framing Berita Penangkapan Gubernur Riau Annas Maamun di Surat Kabar Riau Pos dan Tribun Pekanbaru”, Jurnal Komunikasi Global, Vol. 6, No. 2, 2017, hal. 220-238.

20 Suharyo, "Optimalisasi Pemberantasan Korupsi dalam Era Desentralisasi di Indonesia”, Jurnal Rechtsvinding, Vol. 3, No. 3, Desember 2014, hal. 365-380.
} 
Selain lima tulisan tersebut, terdapat tulisan ilmiah mengenai OTT yang berjudul "Operasi Tangkap Tangan oleh KPK”, yang ditulis oleh Luthvi Febryka Nola, dimuat dalam Info Singkat Vol. V No. 24/II/P3DI/Desember 2013, yang diterbitkan oleh Pusat Pengkajian Pengolahan Data dan Informasi Setjen DPR RI. Namun, tulisan ini merupakan studi kepustakaan dan fokus pada OTT yang dilakukan oleh KPK saja.

Sementara itu, penelitian ini mengkaji OTT yang dilakukan, tidak hanya oleh KPK, tetapi juga penyidik tindak pidana korupsi lainnya, yaitu kepolisian dan kejaksaan yang tergabung dalam Satgas Saber Pungli, dan membandingkannya. Objek yang diteliti adalah tindak pidana korupsi pada umumnya, tidak spesifik pada gratifikasi saja. Metode penelitian yang digunakan dalam tulisan ini adalah yuridis normatif dan yuridis empiris, sehingga didukung oleh data dan pendapat stakeholders terkait, yang diperoleh Penulis dalam penelitian di dua daerah, yaitu Provinsi Jawa Timur dan Provinsi D.I. Yogyakarta.

\section{METODE PENELITIAN}

Penelitian tentang "Operasi Tangkap Tangan dalam Penanganan Kasus Korupsi” merupakan penelitian yuridis normatif dan yuridis empiris. Dalam kaitan dengan penelitian ini, dikaji dasar hukum OTT dan pelaksanaan OTT oleh KPK dan Satgas Saber Pungli. Berdasarkan metode pendekatan yang digunakan, maka penelitian ini menggunakan pendekatan normatif. Metode penelitian dilakukan dengan kajian norma hukum dalam undang-undang dan peraturan perundang-undangan, studi kepustakaan untuk mengumpulkan doktrin hukum, dan wawancara terhadap narasumber dengan menggunakan pedoman wawancara (interview guide) yang telah disiapkan sebelumnya. Bahan hukum yang terkumpul dianalisis dengan metode analisis yuridis normatif dan yuridis empirik dan diuraikan secara deskriptif.

Adapun bahan hukum yang digunakan dalam penelitian ini adalah bahan hukum primer (primary sources) dan bahan hukum sekunder (secondary sources). Primary sources yang dimaksudkan adalah peraturan perundang- undangan yang terkait dengan penangkapan dalam hukum acara penanganan kasus korupsi, antara lain UU Tipikor, UU KPK, dan KUHAP. Sedangkan secondary sources yang dimaksudkan adalah ulasan atau komentar para pakar yang terdapat dalam buku dan jurnal, termasuk yang dapat diakses melalui internet.

Penelitian ini dilengkapi dengan data primer, terutama berkaitan dengan data dan informasi mengenai OTT. Dalam rangka itu, maka wawancara dilakukan dengan pihak-pihak yang berkompeten, yaitu aparat penegak hukum (polisi, jaksa, dan hakim), akademisi yang memiliki kompetensi dalam masalah hukum pidana, dan advokat. Wawancara dilakukan dengan stakeholders yang berada di Provinsi D.I. Yogyakarta (17 - 23 April 2017) dan Provinsi Jawa Timur (Jatim) (15 - 21 Mei 2017).

Pemilihan Provinsi Jatim didasarkan pada pertimbangan, bahwa Provinsi Jatim merupakan daerah kedua terbanyak OTT yang dilakukan oleh Satgas Saber Pungli, setelah Jawa Barat. Selain itu, OTT Kasus Suap Kapal PT Penataran Angkatan Laut (PT PAL) yang dilakukan oleh KPK, terjadi di Surabaya. ${ }^{21}$ Sedangkan pemilihan Provinsi D.I. Yogyakarta didasarkan pada OTT yang dilakukan terhadap Bupati Klaten Sri Hartini oleh KPK, karena diduga menerima suap dalam kasus jual beli jabatan di lingkungan Pemerintah Kabupaten Klaten. Kuasa hukum Sri Hartini berdomisili di Yogyakarta, sehingga Penulis dapat memperoleh data dan informasi dari kuasa hukum tersebut. Pengumpulan data dan informasi di kedua Provinsi tersebut dilakukan di berbagai tempat yang dapat memberikan kontribusi dalam penelitian.

\section{MODEL HUKUM ACARA PIDANA: CRIME CONTROL MODEL DAN DUE PROCESS MODEL}

Penegakan hukum merupakan salah satu upaya untuk menciptakan ketertiban,

\footnotetext{
21 "Kasus Suap Kapal, Ini Kronologi Operasi Tangkap Tangan KPK”, Tempo.com, 1 April 2017. https://nasional. tempo.co/read/861572/kasus-suap-kapal-ini-kronologioperasi-tangkap-tangan-kpk, https://nasional.tempo.co/ $\mathrm{read} / 861572 /$ kasus-suap-kapal-ini-kronologi-operasitangkap-tangan-kpk, diakses tanggal 1 April 2017.
} 
keamanan, dan ketenteraman dalam masyarakat. Dilihat secara fungsional, sistem penegakan hukum merupakan suatu sistem aksi. Ada sekian banyak aktivitas yang dilakukan oleh alat perlengkapan negara dalam penegakan hukum.

Proses penegakan hukum harus memperhatikan ketentuan hukum acara pidana. UU tidak memberikan pengertian mengenai hukum acara pidana, tetapi yang ada adalah berbagai pengertian mengenai bagian tertentu dari hukum acara pidana, misalnya penyelidikan, penyidikan, dan penangkapan. Pengertian hukum acara pidana dikemukakan oleh para pakar, yang dapat ditemukan dalam berbagai literatur. Moeljatno menyebutkan, hukum acara pidana adalah bagian dari keseluruhan hukum yang berlaku di suatu negara, yang memberikan dasar-dasar dan aturan-aturan yang menentukan dengan cara apa dan prosedur macam apa, ancaman pidana yang ada pada suatu perbuatan pidana dapat dilaksanakan apabila ada sangkaan bahwa orang telah melakukan delik tersebut. ${ }^{22}$

Adapun yang menjadi tujuan dari hukum acara pidana dalam pedoman pelaksanaan KUHAP, adalah untuk mencari dan mendapatkan atau setidak-tidaknya mendekati kebenaran materiil, ialah kebenaran yang selengkap-lengkapnya dari suatu perkara pidana dengan menerapkan ketentuan hukum acara pidana secara jujur dan tepat, dengan tujuan untuk mencari siapakah pelaku yang tepat didakwakan melakukan suatu pelanggaran hukum, dan selanjutnya meminta pemeriksaan dan putusan dari pengadilan guna menemukan apakah terbukti bahwa tindak pidana telah dilakukan dan apakah orang yang didakwa itu dapat dipersalahkan. ${ }^{23}$

Hukum acara pidana pertama kali diklasifikasikan oleh Herbert L. Packer pada tahun 1964 dalam 2 model, yaitu Crime Control dan Due Process. Klasifikasi dilakukan dengan tujuan untuk mengidentifikasi persoalan-

\footnotetext{
22 Moeljatno, Hukum Acara Pidana, Yogyakarta: Penerbit Universitas Gajah Mada, 1981, hal. 1.

23 Ibid., hal. 4
}

persoalan yang ada dalam hukum acara pidana dan kemudian memberikan solusi normatif yang mungkin dilakukan. Crime Control Model (CCM) dan Due Process Model (DPM) membantu mengenal "sistem operasi" yang dipakai dalam hukum acara pidana. ${ }^{24}$

CCM berawal dari fenomena tingginya tingkat kejahatan sebagai akibat tidak meratanya pertumbuhan ekonomi dan untuk menanggulanginya maka negara menggunakan sarana hukum pidana. ${ }^{25}$ Adapun nilai-nilai yang melandasi CCM berupa:

1. Tindakan represif terhadap suatu tindakan kriminal merupakan fungsi terpenting dari suatu proses peradilan;

2. Perhatian utama harus ditujukan kepada efisiensi dari suatu penegakan hukum untuk menyeleksi tersangka, menetapkan kesalahannya dan menjamin atau melindungi hak tersangka dalam proses peradilannya;

3. Proses kriminal penegakan hukum harus dilaksanakan berdasarkan prinsip cepat (speedy) dan tuntas (finality) dan model yang dapat mendukung proses penegakan hukum tersebut adalah model administratif yang menyerupai metode manajerial;

4. Asas praduga bersalah adalah prasyarat untuk efisiensi pelaksanaan sistem; dan

5. Proses penegakan hukum harus menitikberatkan kepada kualitas temuan fakta administratif karena temuan tersebut akan membawa ke arah (a) pembebasan tersangka dari penuntutan, atau (b) tersangka menyatakan dirinya bersalah atau plead guilty. ${ }^{26}$

Berbeda dengan CCM yang menitikberatkan penyelesaian perkara pidana melalui sarana hukum pidana, DPM lebih menekankan penyelesaian perkara dengan mendudukkan penuntut umum dan terdakwa sebagai subjek

24 Herbert L. Packer, The Limits of Criminal Sanction: Two Models of The Criminal Process, sebagaimana dikutip oleh Aristo M.A. Pangaribuan, Arsa Mufti, dan Ichsan Zikry, Pengantar Hukum Acara Pidana di Indonesia, Jakarta: Rajawali Pers, 2017, hal. 12.

25 Ibid., hal. 13.

26 Ibid., hal. 14 
yang sama. DPM beranggapan bahwa proses peradilan pidana harus bersifat formal, dalam artian menekankan pada pencarian fakta melalui prosedur formal, atau melalui proses atau keterlibatan lembaga pengadilan yang independen dan memerhatikan kondisi berupa telah terpenuhinya hak dasar seorang tersangka, seperti didampingi penasihat hukum. Nilai-nilai yang melandasi DPM di antaranya berupa:

1. Menolak informal fact finding process karena membuka faktor kesalahan manusia lebih besar sehingga dalam menentukan seseorang yang factually guilt hanya dengan melakukan metode formal adjudicative dan adversary fact finding;

2. Menekankan kepada pencegahan dan penghapusan sejauh mungkin kesalahan mekanisme administrasi peradilan;

3. Beranggapan bahwa menempatkan individu secara utuh dan utama di dalam proses peradilan dan konsep pembatasan wewenang adalah hal yang sangat penting;

4. Bertitik tolak dari nilai yang bersifat antiauthoritarian sehingga memegang teguh doktrin legal guilt; dan

5. Kesetaraan di muka umum menjadi hal yang sangat penting, yang dijewantahkan dengan sikap pemerintah yang menyediakan fasilitas yang sama untuk setiap orang yang berurusan dengan hukum. ${ }^{27}$

\section{PENANGKAPAN DAN TANGKAP TANGAN MENURUT HUKUM ACARA PIDANA}

Dalam hukum acara pidana, pejabat tertentu diberi kewenangan untuk melakukan pembatasan terhadap kebebasan dan kemerdekaan seseorang dalam berbagai bentuk kegiatan. Pembatasan kebebasan dan kemerdekaan ini merupakan suatu tindakan atau upaya paksa yang harus dilakukan dalam mengikuti perintah UU. KUHAP telah menentukan adanya beberapa tindakan atau upaya paksa yang dapat dilakukan sehubungan dengan terjadinya tindak pidana yang dilakukan oleh seseorang. KUHAP memberikan

27 Ibid., hal. 15-16. wewenang kepada penyidik, antara lain wewenang untuk mengurangi kebebasan dan hak asasi seseorang. Penggunaan wewenang ini harus tetap berlandaskan hukum dan prinsipprinsip yang menjunjung tinggi harkat martabat manusia dan menjamin keseimbangan antara perlindungan kepentingan tersangka pada satu pihak, dan kepentingan masyarakat luas, kepentingan umum pada pihak lain. ${ }^{28}$

Wewenang yang diberikan UU kepada penyidik yang bersifat pembatasan kebebasan dan hak asasi seseorang dapat dilakukan dalam bentuk tindakan penangkapan, penahanan, penyitaan, dan penggeledahan. Penangkapan adalah suatu tindakan penyidik berupa pengekangan sementara waktu kebebasan tersangka atau terdakwa apabila terdapat cukup bukti guna kepentingan penyidikan atau penuntutan dan/atau peradilan dalam hal serta menurut cara yang diatur dalam undangundang ini. ${ }^{29}$

Pejabat yang berwenang melakukan penangkapan adalah:

a. Penyelidik atas perintah penyidik berwenang melakukan penangkapan untuk kepentingan penyidikan.

b. Penyidik dan penyidik pembantu berwenang melakukan penangkapan untuk kepentingan penyidikan. ${ }^{30}$

Pasal 17 KUHAP menentukan, bahwa penyelidik dan penyidik/penyidik pembantu melakukan penangkapan terhadap seseorang yang diduga keras melakukan tindak pidana, dan harus berdasarkan bukti permulaan yang cukup. ${ }^{31}$ Ketentuan ini menunjukkan bahwa perintah penangkapan tidak dapat dilakukan dengan sewenang-wenang tetapi ditujukan kepada mereka yang benar-benar melakukan tindak pidana.

Definisi "bukti permulaan yang cukup" sesungguhnya masih belum jelas, sehingga dalam praktik masalah ini sangat tergantung

\footnotetext{
Ramelan, Hukum Acara Pidana (Teori dan Implementasi), Jakarta: Sumber Ilmu Jaya, 2006, hal. 84.

29 Pasal 1 angka 20 KUHAP.

Pasal 16 KUHAP.

Pasal 17 KUHAP.
} 
pada penilaian obyektif penyelidik dan penyidik. Yang dimaksud dengan "bukti permulaan yang cukup" dijelaskan dalam Penjelasan Pasal 17 KUHAP, adalah bukti permulaan untuk menduga adanya tindak pidana, sesuai dengan bunyi Pasal 1 angka 14 KUHAP. ${ }^{32}$ Namun, sebagai pedoman dalam praktik biasanya didasarkan adanya keterangan saksi yang menunjukkan tersangka sebagai pelakunya didukung alat bukti lain, seperti alat bukti petunjuk berupa barang bukti, dan sebagainya. ${ }^{33}$

Merujuk pada Pasal 17 KUHAP beserta penjelasannya, tidak ada ketentuan yang eksplisit menyebutkan apa saja bukti permulaan yang cukup itu. Namun kemudian, dalam Putusan Mahkamah Konstitusi (MK) Nomor 21/PUU-XII/2014 dinyatakan bahwa frasa "bukti permulaan", "bukti permulaan yang cukup", dan "bukti yang cukup" sebagaimana ditentukan dalam Pasal 1 angka 14, Pasal 17, dan Pasal 21 ayat (1) KUHAP harus ditafsirkan sekurang-kurangnya dua alat bukti yang termuat dalam Pasal 184 KUHAP. ${ }^{34}$ Adapun alat bukti yang sah menurut Pasal 184 ayat (1) KUHAP ialah keterangan saksi; keterangan ahli; surat; petunjuk; dan keterangan terdakwa.

MK beralasan KUHAP tidak memberi penjelasan mengenai batasan jumlah (alat bukti) dari frasa "bukti permulaan", "bukti permulaan yang cukup", dan "bukti yang cukup". Mahkamah menganggap syarat minimum dua alat bukti dan pemeriksaan calon tersangka untuk transparansi dan perlindungan hak asasi seseorang agar sebelum seseorang ditetapkan sebagai tersangka telah dapat memberi keterangan secara seimbang. Hal ini menghindari adanya tindakan sewenangwenang oleh penyidik terutama dalam menentukan bukti permulaan yang cukup itu.

Pelaksanaan tugas penangkapan dilakukan oleh penyidik dengan memperlihatkan surat tugas serta memberikan kepada tersangka surat

Penjelasan Pasal 17 KUHAP.

Ramelan, op. cit, hal. 85.

34 Putusan MK Nomor 21/PUU-XII/2014 mengenai Permohonan Pengujian UU No. 8 Tahun 1981 tentang Hukum Acara Pidana terhadap Undang-Undang Dasar Negara Republik Indonesia Tahun 1945. perintah penangkapan yang mencantumkan identitas tersangka dan menyebutkan alasan penangkapan serta uraian singkat perkara kejahatan yang dipersangkakan serta tempat ia diperiksa. Dalam hal tertangkap tangan penangkapan dilakukan tanpa surat perintah, dengan ketentuan bahwa penangkap harus segera menyerahkan tertangkap beserta barang bukti yang ada kepada penyidik atau penyidik pembantu yang terdekat.

Dalam hal pelaku tertangkap tangan, harus dipenuhi syarat tertangkap tangan yang bersifat alternatif, artinya apabila salah satu terpenuhi, dapat dikategorikan tertangkap tangan. Namun, dalam ketentuan tersebut ada kelemahan, yaitu tidak menjelaskan berapa lama yang dimaksud "dengan segera sesudah beberapa saat tindak pidana dilakukan" dan "apabila sesaat kemudian padanya ditemukan benda ...".

Mengingat tertangkap tangan adalah masuk ranah penangkapan, maka berdasarkan Pasal 19 ayat (1) KUHAP penangkapan dapat dilakukan untuk paling lama satu hari. Dengan demikian, masalah pelaksanaan tangkap tangan yang dilakukan oleh penyidik dalam penanganan tindak pidana termasuk tindak pidana korupsi, dikatakan sah apabila telah memenuhi salah satu syarat sebagaimana dimaksud pada huruf a sampai dengan huruf e.

Sementara itu, OTT tidak disebut dalam KUHAP dan UU Tipikor, serta UU KPK. OTT adalah istilah KPK untuk "menangkap basah" seseorang yang diduga sebagai pelaku korupsi. Sebuah operasi yang rahasia, terukur dan jarang korbannya dapat selamat dari tuduhan karena didasari dengan proses yang panjang ketika KPK "mengendus" adanya korupsi. ${ }^{35}$

Istilah OTT baru muncul dalam Peraturan Presiden Republik Indonesia (Perpres) Nomor 87 Tahun 2016 tentang Satuan Tugas Sapu Bersih Pungutan Liar. Perpres Nomor 87 Tahun 2016 membentuk Satuan Tugas Sapu Bersih Pungutan Liar yang selanjutnya disebut Satgas

35 Fatimah Asyari, "Operasi Tangkap Tangan di Pusat dan Daerah untuk Meraih WTP Terkait Masalah Pelanggaran Hukum", Jurnal Legalitas, Vol. 2 No.1, Juni 2017, hal. 57-66. 
Saber Pungli, yang berkedudukan di bawah dan bertanggung jawab kepada Presiden. ${ }^{36}$

Menteri Koordinator Bidang Politik, Hukum, dan Keamanan merupakan penanggungjawab Satgas Saber Pungli, dengan Ketua Pelaksana Inspektur Pengawasan Umum Polri. Adapun yang menjadi tugas Satgas Saber Pungli adalah melaksanakan pemberantasan pungutan liar secara efektif dan efisien dengan mengoptimalkan pemanfaatan personil, satuan kerja, dan sarana prasarana, baik yang berada di kementerian/ lembaga maupun pemerintah daerah. ${ }^{37}$ Dalam melaksanakan tugas dan fungsinya, Satgas Saber Pungli mempunyai sejumlah wewenang, salah satunya adalah melakukan operasi tangkap tangan. Apa yang dimaksud dengan operasi tangkap tangan tidak dijelaskan dalam Perpres Nomor 87 Tahun 2016.

Di tingkat daerah Tim Saber Pungli dibentuk dengan Surat Keputusan Gubernur. Masa kerja Tim Saber satu tahun, dengan anggaran dari gubernur dan kabupaten/kota dengan angaran dari bupati/walikota. Di Jawa Timur contohnya, Tim Saber Pungli dibentuk dengan Surat Keputusan Gubernur No. 188/624/KPTS/013/2016 tentang Unit Satuan Tugas Sapu Bersih Pungli Provinsi Jawa Timur, tanggal 4 November 2016. Anggaran dari gubernur sebesar 3 milyar setahun. ${ }^{38}$

Satgas Saber Pungli beranggotakan antara lain: Kepolisian, Biro Hukum Pemda, Inspektorat, Kejaksaan, Intelijen, Ombudsman, Pakar/Akademisi. Struktur Saber Pungli terdiri atas Sub Satgas Intelijen, Sub Satgas Pencegahan, dan Sub Satgas Penindakan. Jadi Saber tidak hanya melakukan penindakan. Hasil kerja Saber Pungli dilaporkan kepada atasan masing-masing. ${ }^{39}$

\section{PELAKSANAAN OTT}

\section{A. Pelaksanaan OTT oleh KPK}

Tipe atau kualitas sasaran korupsi bukan merupakan tindak pidana

Pasal 1 Perpres Nomor 87 Tahun 2016.

Pasal 2 Perpres Nomor 87 Tahun 2016.

Wawancara dengan Kompol Joes Indra Lana Wira, Penyidik Tipikor Polda Jawa Timur, 16 Mei 2017.

39 Ibid. yang sederhana dari sudut pelaku dan modus operandinya. Ada bermacam-macam istilah yang digunakan untuk menyebut tindak pidana korupsi, di antaranya adalah sebagai salah satu bentuk dari crime as bussiness, economic crimes, white collar crime, official crime, atau abuse of power. ${ }^{40}$ Modus operandi korupsi secara umum adalah pemberian suap (bribery), pemalsuan (fraud), pemerasan (exortion), penyalahgunaan jabatan atau wewenang (abuse or discretion), dan nepotisme (nepotism). ${ }^{41}$

Dalam konteks hukum pidana, korupsi merupakan tindak pidana yang sulit dibuktikan. Dalam kasus suap misalnya, biasanya antara pemberi suap dan penerima suap melakukan silent operation untuk mewujudkan kejahatan tersebut. Bahkan sedapat mungkin meniadakan bukti-bukti bahwa tindak pidana tersebut telah dilakukan. KPK memiliki sistem untuk melakukan penanggulangan kasus korupsi yaitu dengan OTT. Tidak dapat dipungkiri bahwa terungkapnya banyak kasus korupsi, seperti suap impor daging sapi yang menyeret mantan Ketua Partai Keadilan Sejahtera Luthfi Hasan Ishaaq dan suap SKK Migas yang melibatkan Rudi Rubiandini, tidak terlepas dari OTT.

Dalam melakukan OTT ada dua teknik yang digunakan oleh KPK yaitu penyadapan dan penjebakan. ${ }^{42} \mathrm{UU}$ KPK hanya menyebut kewenangan penyadapan, tidak mengatur prosedurnya, sedangkan penjebakan tidak dikenal dalam berbagai aturan tentang korupsi di Indonesia. Akibatnya dalam penggunaannya, kedua teknik tersebut sering menimbulkan opini bahwa KPK melakukan pelanggaran hukum dan hak asasi manusia (HAM). Ketidakjelasan mengenai mekanisme dan batasan kewenangan penyadapan yang dilakukan oleh KPK tersebut memunculkan asumsi publik bahwa kewenangan penyadapan oleh KPK tersebut

\footnotetext{
40 Elwi Danil, Korupsi Konsep, Tindak Pidana, dan Pemberantasannya, Jakarta: PT RajaGrafindo Persada, 2012, hal. 61.

41 Rohim, Modus Operandi Tindak Pidana Korupsi, Jakarta: Pena Multi Media, 2008, hal. 20.

42 “Operasi Tangkap Tangan oleh KPK”, 1 Februari 2017, https://www.nyatnyut.com/2017/02/01/operasi-tangkaptangan-oleh-kpk/, diakses tanggal 14 Mei 2017.
} 
telah melanggar hukum bahkan melanggar HAM yakni melanggar hak privasi seseorang.

Beberapa Putusan MK yang berkaitan dengan penyadapan ${ }^{43}$, antara lain mengatakan bahwa Pasal 12 ayat (1) huruf a UU KPK mengenai kewenangan KPK dalam penyadapan bertentangan dengan Pasal 28G ayat (1) Undang-Undang Dasar Negara Republik Indonesia Tahun 1945 (UUD Tahun 1945), yang menyebutkan bahwa "Setiap orang berhak atas perlindungan diri pribadi, keluarga, kehormatan, martabat, dan harta benda yang di bawah kekuasaannya, serta berhak atas rasa aman dan perlindungan dari rasa ketakutan untuk berbuat atau tidak berbuat sesuatu yang merupakan hak asasi."Namun, MK menjelaskan hak privasi bukanlah bagian dari hak-hak yang tidak dapat dikurangi dalam keadaan apapun (nonderogable rights), sehingga negara dapat melakukan pembatasan terhadap pelaksanaan hak-hak tersebut dengan menggunakan UU, sebagaimana diatur dalam Pasal 28J ayat (2) UUD Tahun 1945. MK mengamanatkan untuk membentuk satu aturan tentang mekanisme dan prosedur penyadapan yang berisi syaratsyarat:

1. adanya otoritas resmi yang ditunjuk dalam UU untuk memberikan izin penyadapan,

2. adanya jaminan jangka waktu yang pasti dalam melakukan penyadapan,

3. pembatasan penanganan materi hasil penyadapan, dan

4. pembatasan mengenai orang yang dapat mengakses penyadapan.

Sampai saat ini UU yang secara khusus mengatur penyadapan belum dibentuk. Sementara itu, KPK terus melakukan OTT. Tiga pekan setelah pelantikan, Ketua KPK Agus Rahardjo

Tabel 2. Daftar OTT yang Dilakukan oleh KPK pada 2016

\begin{tabular}{|c|c|c|}
\hline Bulan & Orang yang Tertangkap Tangan & Perkara \\
\hline \multirow[t]{2}{*}{ Desember } & Bupati Klaten, Sri Hartini & Suap terkait promosi jabatan di Pemkab Klaten \\
\hline & $\begin{array}{l}\text { Wali Kota Cimahi, Atty Suharti bersama suaminya } \\
\text { Ittoch Tochija }\end{array}$ & $\begin{array}{l}\text { Suap dalam proyek pembangunan Pasar Atas Baru } \\
\text { Cimahi }\end{array}$ \\
\hline \multirow[t]{2}{*}{ September } & Ketua DPD RI, Irman Gusman & Gratifikasi kuota impor gula \\
\hline & Bupati Banyuasin, Yan Anton Ferdian dan isterinya & $\begin{array}{l}\text { Suap sebesar Rp. } 1 \text { miliar dari pengusaha bernama } \\
\text { Zulfikar terkait izin proyek di Dinas Pendidikan } \\
\text { Banyuasin. }\end{array}$ \\
\hline \multirow[t]{3}{*}{ Juni } & $\begin{array}{l}\text { Panitera Pengadilan Negeri Jakarta Utara Rohadi dan } \\
\text { Pengacara Saipul Jamil Berta Natalia, serta Samsul } \\
\text { Hidayatullah kakak kandung Saipul Jamil. }\end{array}$ & $\begin{array}{l}\text { Suap agar Saipul diberikan putusan ringan untuk } \\
\text { perkara pencabulan anak di bawah umur yang sedang } \\
\text { menjeratnya. }\end{array}$ \\
\hline & Anggota Komisi III DPR Putu Sudiartana & $\begin{array}{l}\text { Suap untuk alokasi rencana pembangunan } 12 \text { ruas } \\
\text { jalan di Sumatera Barat (Sumbar). }\end{array}$ \\
\hline & Panitera Pengadilan Negeri Jakarta Pusat, Santoso & $\begin{array}{l}\text { Suap terkait penanganan perkara perdata PT KTP } \\
\text { dan PT MMS }\end{array}$ \\
\hline Mei & $\begin{array}{l}\text { Hakim Pengadilan Tindak Pidana Korupsi di } \\
\text { Bengkulu, Janner Purba }\end{array}$ & $\begin{array}{l}\text { Korupsi honor pembina Rumah Sakit M Yunus, } \\
\text { Bengkulu }\end{array}$ \\
\hline
\end{tabular}

$43 \quad$ Putusan MK No. 006/PUU-I/2003 mengenai Permohonan Pengujian UU No. 30 Tahun 2002 tentang Komisi Pemberantasan Tindak Pidana Korupsi terhadap UUD Tahun 1945, Putusan MK No. 012-016-019/PUU. IV/2006 mengenai Permohonan Pengujian UU No. 30 Tahun 2002 tentang Komisi Pemberantasan Tindak Pidana Korupsi terhadap UUD Tahun 1945, dan Putusan MK No. 05/PUU-VIII/2010 mengenai Pengujian Pasal 31 ayat (4) UU No. 11 Tahun 2008 tentang Informasi dan Transaksi Elektronik terhadap UUD Tahun 1945. memenuhi janjinya dengan menangkap tangan Anggota Komisi V DPR dari Fraksi PDI Perjuangan: Damayanti Wisnu Putranti. Daftar OTT yang telah dilakukan oleh KPK pada tahun 2016, dapat dilihat pada tabel 2. 


\begin{tabular}{|c|c|c|}
\hline \multirow[t]{2}{*}{ April } & $\begin{array}{l}\text { Bupati Subang Ojang Sohandi, Jaksa dari Kejaksaan } \\
\text { Tinggi (Kejati) Jawa Barat Devianti Roachaeni, Fahri } \\
\text { Nurmallo (jaksa lainnya) }\end{array}$ & $\begin{array}{l}\text { Suap untuk meringankan tuntutan terhadap Bupati } \\
\text { Subang Ojang Suhandi dan mengamankan Ojang agar } \\
\text { tidak tersangkut kasus korupsi penyalahgunaan dana } \\
\text { BPJS tahun anggaran } 2014 \text {. }\end{array}$ \\
\hline & $\begin{array}{l}\text { Panitera/Sekretaris (Pansek) Pengadilan Negeri } \\
\text { (PN) Jakarta Pusat Edy Nasution dan seorang swasta } \\
\text { bernama Doddy Aryanto Supeno }\end{array}$ & $\begin{array}{l}\text { Penyuapan untuk memuluskan permohonan } \\
\text { peninjauan kembali (PK) perkara perdata yang } \\
\text { didaftarkan di PN Jakarta Pusat. }\end{array}$ \\
\hline \multirow[t]{2}{*}{ Maret } & $\begin{array}{l}\text { Ketua Komisi D DPRD DKI Jakarta M Sanusi, } \\
\text { Presiden Direktur PT Agung Podomoro Land (APL) } \\
\text { Ariesman Widjaja, dan karyawan PT APL Trinanda } \\
\text { Prihantoro. }\end{array}$ & $\begin{array}{l}\text { Suap pembahasan Raperda tentang Rencana Zonasi } \\
\text { Wilayah Pesisir dan Pulau-Pulau Kecil Provinsi Jakarta } \\
\text { Tahun 2015-2035 dan Raperda tentang Rencana Tata } \\
\text { Ruang Kawasan Strategis Pantai Jakarta Utara (Reklamasi). }\end{array}$ \\
\hline & $\begin{array}{l}\text { Pada hari yang sama: } \\
\text { Direktur Keuangan PT Brantas Abipraya (BUMN) } \\
\text { Sudi Wantoko, Senior Manajer PT Brantas Abipraya } \\
\text { Dandung Pamularno, dan Marudut (swasta). }\end{array}$ & $\begin{array}{l}\text { Penyuapan untuk menghentikan penyelidikan } \\
\text { atau penyidikan tindak pidana korupsi PT Brantas } \\
\text { Abipraya di Kejaksaan Tinggi DKI Jakarta. }\end{array}$ \\
\hline Februari & $\begin{array}{l}\text { Kepala Sub Direktorat Kasasi Perdata Direktorat } \\
\text { Panata dan Tata Laksana Perkara Perdata Badan } \\
\text { Peradilan Umum Mahkamah Agung, Andri Tristianto } \\
\text { Sutrisna. Awang Lazuardi, Ichsan Suaidi (Direktur PT } \\
\text { Citra Gading Asritama). }\end{array}$ & $\begin{array}{l}\text { Suap untuk menunda pemberian salinan putusan } \\
\text { perkara korupsi ke Pengadilan Negeri (PN) Mataram. }\end{array}$ \\
\hline Januari & $\begin{array}{l}\text { Anggota DPR Damayanti Wisnu Putranti dan lima } \\
\text { orang lain. }\end{array}$ & Penyuapan dari Dirut PT Windu Tunggal Utama. \\
\hline
\end{tabular}

Sumber: diolah dari beberapa sumber

Sementara itu, jumlah kasus OTT yang 72 orang sebagai tersangka dengan berbagai profil dilakukan oleh KPK dalam tahun 2017 melampaui tersangka mulai dari aparat penegak hukum, jumlah tahun 2016 dan merupakan jumlah anggota legislatif, dan kepala daerah. Daftar 19 terbanyak sepanjang KPK berdiri. Sebanyak 19 kasus OTT yang dilakukan oleh KPK selama kasus merupakan hasil OTT, dengan penetapan tahun 2017, dapat dilihat pada tabel 3.

Tabel 3. Daftar OTT yang Dilakukan oleh KPK pada 2017

\begin{tabular}{|c|c|c|c|}
\hline No. & Bulan & Orang yang Tertangkap Tangan & Perkara \\
\hline 1. & Januari & Hakim Konstitusi, Patrialis Akbar & $\begin{array}{l}\text { Suap terkait judicial review UU No. } 41 \\
\text { Tahun } 2014 \text { tentang Peternakan dan } \\
\text { Kesehatan Hewan. }\end{array}$ \\
\hline 2. & Maret & Direktur Utama PT PAL M. Firmansyah Arifin & $\begin{array}{l}\text { Suap dalam pembelian kapal perang } \\
\text { oleh Pemerintah Filipina }\end{array}$ \\
\hline 3. & Mei & $\begin{array}{l}\text { Auditor BPK Ali Sadli dan Irjen Kemendes PDTT } \\
\text { Rochmadi Saptogiri }\end{array}$ & $\begin{array}{l}\text { Suap dalam pemberian opini wajar } \\
\text { tanpa pengecualian (WTP) untuk } \\
\text { Kemendes PDTT }\end{array}$ \\
\hline 4. & Juni & $\begin{array}{l}\text { Enam orang tersangka termasuk Bambang Heryanto } \\
\text { (Kadis Pertanian Jatim), Rohayati (Kadis Peternakan } \\
\text { Jatim), dan M. Basuki (Ketua Komisi B DPRD Jatim) }\end{array}$ & $\begin{array}{l}\text { Suap pengawasan anggaran dan Perda } \\
\text { yang dilakukan oleh Komisi B DPRD } \\
\text { Jatim terhadap SKPD di Jatim }\end{array}$ \\
\hline 5. & Juni & $\begin{array}{l}\text { Kepala Seksi III Intel Kejaksaan Tinggi Bengkulu } \\
\text { Parlin Purba }\end{array}$ & $\begin{array}{l}\text { Suap terkait proyek-proyek Balai } \\
\text { Wilayah Sungai Sumatra VII Bengkulu }\end{array}$ \\
\hline 6. & Juni & $\begin{array}{l}4 \text { orang tersangka, yaitu Purnomo (Ketua DPRD } \\
\text { Mojokerto), Abdullah Fanani (Wakil Ketua DPRD } \\
\text { Mojokerto), Umar Faruq (Wakil Ketua DPRD Mojokerto), } \\
\text { dan Wiwiet Febryanto (Kadis PUPR Mojokerto) }\end{array}$ & $\begin{array}{l}\text { Suap dari Dinas PU dan Penataan } \\
\text { Ruang Kota Mojokerto }\end{array}$ \\
\hline
\end{tabular}




\begin{tabular}{llll}
\hline 7. & Juni & $\begin{array}{l}\text { Gubernur Bengkulu Ridwan Mukti dan isterinya Lily } \\
\text { Martiani Maddari }\end{array}$ & Suap proyek di Pemprov Bengkulu \\
\hline 8. Agustus & $\begin{array}{l}\text { Bupati Pamekasan Achmad Syafii, Sutjipto Utomo } \\
\text { (Kepala Inspektorat Pamekasan), Rudy Indra Prasetya } \\
\text { (Kajari Pamekasan), Agus (Kepala Desa Dassok), dan }\end{array}$ & $\begin{array}{l}\text { Suap untuk menghentikan } \\
\text { penanganan kasus penyelewengan } \\
\text { dana desa }\end{array}$ \\
& $\begin{array}{ll}\text { Noer Solehhoddin (Kabag Administrasi Inspektur } \\
\text { Pamekasan) }\end{array}$ \\
\hline
\end{tabular}

\begin{tabular}{cll}
\hline 9. Agustus & Panitera Pengganti Pengadilan Negeri Jakarta Selatan, & Suap untuk perkara gugatan perdata \\
& Tarmizi dan Pengacara, Akhmad Zaini & Eastern Jason Fabrication Service \\
& Pte Ltd. terhadap PT Aquamarine \\
& Divindo Inspection \\
\hline
\end{tabular}

10. Agustus Dirjen Perhubungan Laut A Tonny Budiono

Suap sebesar Rp20,74 miliar dari

Komisaris PT AGK Adiputra

Kurniawani untuk keperluan perizinan pengerjaan proyek di Pelabuhan Tanjung Mas dan beberapa daerah lainnya.

\begin{tabular}{lll}
\hline 11. & Agustus & Tiga orang ditetapkan sebagai tersangka yaitu Wali \\
& & Kota Tegal Siti Masitha Soeparno, Pengusaha Amir \\
& Mirza Hutagalung, dan Wakil Direktur RSUD \\
& Kardinah Tegal, Cahyo Supardi \\
\hline 12. September & $\begin{array}{l}\text { Dewi Suryana (Hakim Tipikor PN Bengkulu), Hendra } \\
\text { Kurniawan, dan Syuhadatul Islamy. }\end{array}$
\end{tabular}

Suap terkait pengelolaan dana jasa pelayanan RSUD Kardinah Tegal dan pengadaan barang dan jasa di lingkungan pemerintahan kota

Suap dalam vonis terkait persidangan korupsi di Dinas Pengelolaan Aset Bengkulu

\begin{aligned} \hline 13. September & Empat orang tersangka: Ketua DPRD Banjarmasin \\ & Iwan Rusmali, Wakil Ketua DPRD Banjarmasin Andi \\ & Effendi, Direktur Utama PDAM Bandarmasih Muslih, \\ & dan Manajer Keuangan PDAM Bandarmasih Trensis \end{aligned}

14. September Lima orang tersangka: Bupati Batubara OK Arya Zulkarnain, Kepala Dinas PUPR Pemkab Batubara Helman Herdady, pemilik dealer mobil Sujendi Tarsono, maringan Situmorang dan Syaiful Azhar

Suap persetujuan Perda tentang penanaman penyertaan modal PDAM Bandarmasih Kota Banjarmasin Suap pembangunan infrastruktur di Kabupaten Batubara \begin{tabular}{lll}
\hline 15. September & Tiga orang tersangka yakni Wali Kota Batu Eddy & Suap pengadaan barang dan jasa di \\
& Rumpoko, Kepala Bagian Layanan dan Pengadaan \\
& Pemkot Batu Edi Setyawan, dan pengusaha Filipus & \\
Djap &
\end{tabular}

16. September Wali Kota Cilegon Tubagus Iman Ariyadi Suap Rp1,5 miliar terkait izin pembangunan Transmart

$\begin{array}{ll}\text { 17. Oktober } & \text { Anggota DPR Komisi XI Aditya Anugrah Moha dan } \\ & \text { Ketua Pengadilan Tinggi Sulawesi Utara Sudiwardono }\end{array}$

18. Oktober Bupati Nganjuk Taufiqurrahman Suap terkait penanganan putusan banding ibu dari Aditya, Marlina Moha Siahaan.

Jual beli jabatan di Kabupaten Nganjuk

\begin{tabular}{lll}
\hline 19. November & Empat orang tersangka (Plt Sekda Jambi Erwan Malik, & Suap pengesahan Rancangan APBD \\
& Asisten III Pemprov Jambi Saifuddin, Plt Kepala Dinas PU & tahun 2018 Provinsi Jambi \\
& Arfan dan Anggota DPRD Jambi Supriono) & \\
\hline
\end{tabular}

Sumber: “Ini Daftar Lengkap 19 OTT KPK Sepanjang 2017”, http://nasional.republika.co.id/berita/nasional/hukum/18/01/01/ p1vv1h409-ini-daftar-lengkap-19-ott-kpk-sepanjang-2017, diakses tanggal 22 Maret 2018. 
Berdasarkan daftar OTT yang telah dilakukan oleh KPK pada tabel 3 tergambar bahwa sasarannya beragam, dari Anggota DPR/ DPD/DPRD, Aparat Penegak Hukum (Hakim dan Jaksa), Pejabat Pemprov, Bupati/Wali Kota, dan Pengusaha. Kasus korupsi yang dipersangkakan berupa suap menyuap, jual beli jabatan/promosi dan terkait penanganan perkara, serta gratifikasi. KPK melakukan OTT setiap saat, bahkan KPK pernah melakukan dua OTT di hari yang sama untuk dua kasus yang berbeda pada Maret dan April 2016.

Berkaitan dengan OTT yang dilakukan oleh KPK, Sumedi (Hakim Pengadilan Tipikor Yogyakarta) berpendapat, KPK tidak selalu salah dan tidak selamanya benar, karena istilah OTT tidak diatur dalam KUHAP. Kata "operasi” diciptakan oleh KPK. KUHAP menyebutkan bahwa tertangkap tangan dilakukan pada waktu sedang melakukan tindak pidana, atau dengan segera sesudah beberapa saat tindak pidana dilakukan, atau sesaat kemudian diserukan oleh khalayak ramai sebagai orang yang melakukannya, atau apabila sesaat kemudian padanya ditemukan barang bukti (Pasal 1 angka 19 KUHAP). Tetapi kalau waktu sudah terlalu lama, maka OTT yang dilakukan oleh KPK tidak memenuhi terminologi tertangkap tangan dalam KUHAP. Namun, ada kelemahan dalam KUHAP yang tidak mengatur secara tegas mengenai "beberapa saat", bagaimana penafsirannya mengenai berapa lama. ${ }^{44}$

Sementara itu, Trimo (Kasi Penyidikan Kejaksaan Tinggi Jatim) mengatakan OTT yang dilakukan oleh KPK didahului dengan penyadapan. OTT hanya merupakan istilah, dalam pelaksanaannya tidak menyalahi KUHAP. Hal itu hanya kesalahan dalam penggunaan istilah. OTT yang dilakukan oleh KPK menunggu sampai ada barang bukti, seperti gratifikasi atau suap. Proses OTT yang dilakukan oleh KPK, tetap sesuai dengan KUHAP, tidak ada perbedaan OTT dan tertangkap tangan sebagaimana diatur KUHAP. ${ }^{45}$

\footnotetext{
$44 \quad$ Wawancara dengan Sumedi dilakukan pada 18 April 2017.
}

45 Wawancara dengan Trimo dilakukan pada 16 Mei 2017.
Pendapat yang sama disampaikan oleh Kombes Polisi Polda Jatim, Widodo, bahwa OTT yang dilakukan oleh KPK didahului dengan penyadapan, kewenangan yang tidak dimiliki oleh Kepolisian. Sebenarnya proses OTT mengacu pada KUHAP dan UU Tipikor, berdasarkan laporan kemudian dilakukan penyelidikan. Berkaitan dengan frasa dalam arti tertangkap tangan "setelah terjadinya" tergantung pada penafsiran aparat, maksudnya kalau dapat dijangkau. ${ }^{46}$

Menurut Oce Madril (Pakar Hukum UGM/Direktur Pukat), tertangkap tangan yang dilakukan oleh KPK bersifat khusus karena KPK mempunyai kewenangan melakukan penyadapan. Perekaman atau penyadapan harus dilihat terpisah dari penangkapan, ada dugaan tindak pidana korupsi. KPK boleh melakukan penyadapan pada tahap penyelidikan, dalam rangka pengumpulan bahan untuk mencari bukti. OTT yang dilakukan oleh KPK masih dianggap tertangkap tangan sebagaimana diatur dalam KUHAP, yaitu pada saat atau setelah tindak pidana korupsi dilakukan. Penyadapan dan tangkap tangan tipikor harus dilihat terpisah. KPK dapat mengikuti orang yang diduga sampai tipikor dilakukan. ${ }^{47}$

Advokat, Deddy Suwadi, ${ }^{48}$ mengatakan proses penangkapan Bupati Klaten, Sri Hartini, pada awalnya karena ada laporan dari pihak tertentu kepada KPK, terkait jual beli jabatan dalam perubahan struktur organisasi perangkat daerah, sesuai dengan UU Pemerintahan Daerah. Pada saat OTT, yang tertangkap tangan adalah orang dinas, yang membantu temannya untuk promosi jabatan, akan menyerahkan uang kepada bupati tersebut. Dasarnya seolaholah sudah disetting, ada unsur jebakan dari pihak-pihak tertentu dalam rangka menggeser jabatan bupati. OTT dilakukan berdasarkan laporan atau informasi dari sumber-sumber/

\footnotetext{
46 Wawancara dengan Kombes Polisi Widodo dilakukan pada 16 Mei 2017.

47 Wawancara dengan Oce Madril dilakukan pada 18 April 2017.

48 Kuasa Hukum Bupati Klaten, Sri Hartini, yang tertangkap tangan oleh KPK, pada 30 Desember 2016 dalam dugaan suap promosi jabatan.
} 
pihak-pihak tertentu yang sengaja menciptakan situasi demikian, KPK menerima laporan, kemudian melakukan pemantauan. Orang yang melaporkan pada umumnya bukan pihak yang dirugikan. Praktik OTT dianggap proses yang paling mudah dilakukan dan pembuktiannya sederhana (75-90\% sudah selesai), 25\% tinggal menambah keterangannya. ${ }^{49}$

Dalam hal OTT yang dilakukan oleh KPK, kuasa hukum tersangka baru dapat menemui kliennya setelah 24 jam, setelah ditetapkan menjadi tersangka. Hal ini tidak sesuai dengan KUHAP. Oleh karena itu, pengawasan terhadap KPK perlu dilakukan, sehingga KPK tidak menjadi superbody atau superpower, harus ada batasan kewenangan yang diberikan terhadap KPK, seperti dalam OTT terhadap Patrialis, harus ada pengembangan perkara. Menurut Deddy, OTT dalam kasus Patrialis tidak tepat karena tidak ada serah terima uang. ${ }^{50}$

Namun, menurut Didik Endro Purwoleksono, Pakar Hukum Universitas Airlangga, OTT tetap dapat dilakukan terhadap tersangka, meskipun KPK tidak menemukan barang bukti pada tersangka pada saat OTT, dengan catatan pada diri tersangka terdapat fakta-fakta hukum:

a. dengan segera sesudah beberapa saat tindak pidana itu dilakukan,

b. sesaat kemudian diserukan oleh khalayak ramai sebagai orang yang melakukannya,

c. apabila sesaat kemudian padanya ditemukan benda yang diduga keras telah dipergunakan untuk melakukan tindak pidana itu yang menunjukkan bahwa ia adalah pelakunya, atau

d. turut melakukan atau membantu melakukan tindak pidana itu. ${ }^{51}$

Lebih lanjut menurut Didik Endro Purwoleksono, OTT yang dilakukan oleh KPK tidak menyalahi hukum acara pidana karena pada diri tersangka ditemukan benda yang diduga keras telah dipergunakan untuk

\footnotetext{
49 Wawancara dengan Deddy Suwadi dilakukan pada 21 April 2017.

50 Ibid.

51 Wawancara dengan Didik Endro Purwoleksono dilakukan pada 17 Mei 2017.
}

melakukan tindak pidana itu yang menunjukkan bahwa ia adalah pelakunya atau tersangka turut melakukan atau membantu melakukan tindak pidana itu. ${ }^{52}$ OTT yang dilakukan oleh KPK juga tidak melanggar asas praduga tak bersalah dan HAM karena KPK melaksanakan OTT sesuai dengan prosedur sebagaimana diatur dalam KUHAP dan UU KPK. Tindakan KPK adalah dalam rangka melaksanakan perintah UU, sehingga merupakan tindakan yang dapat dibenarkan (alasan pembenar), sebagaimana diatur dalam Pasal 50 KUHP. ${ }^{53}$

Berdasarkan hasil wawancara, dapat disimpulkan bahwa OTT yang dilakukan oleh KPK sebenarnya sama dengan terminologi tertangkap tangan dalam KUHAP. KPK menciptakan istilah OTT dan melakukannya didahului dengan penyadapan. Namun, dalam praktik terdapat permasalahan mengenai tafsiran berapa lama yang dimaksud dari frasa "sesudah beberapa saat" dan "sesaat kemudian", tergantung penafsiran aparat.

\section{B. Pelaksanaan OTT oleh Satgas Saber Pungli dan Perbandingannya dengan KPK} Satgas Saber Pungli sudah melakukan OTT di seluruh daerah Indonesia. Ketua Satgas Saber Pungli Komjen Dwi Priyatno mengatakan, sejak dibentuk pada akhir Oktober 2016 Satgas Saber Pungli sudah melakukan 856 OTT. Ada yang dalam proses penyelidikan, penyidikan, penuntutan, sudah P21 (berkas perkara dilimpahkan ke pengadilan), dan sudah divonis. Dari hasil OTT itu, Satgas menyita uang mencapai sekitar Rp13,5 miliar. Selain itu, Satgas juga mengungkap pungli oleh Koperasi Tenaga Kerja Bongkar Muat (TKBM) Samudera Sejahtera (Komura) di Kalimantan Timur. Kasusnya kini ditangani Bareskrim Mabes Polri. Barang bukti kurang lebih Rp326 miliar sudah diblock, dan akan dikembangkan menjadi kasus tindak pidana pencucian uang. ${ }^{54}$

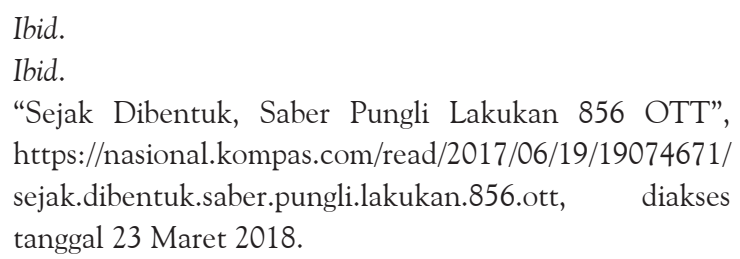


Penyidik Polri menangani kasus korupsi dengan tertangkap tangan berdasarkan laporan. OTT yang dilakukan oleh Polri jumlahnya banyak, tetapi barang bukti uang jumlahnya sedikit dibandingkan dengan OTT yang dilakukan oleh KPK. OTT terhadap pungutan liar (pungli), menurut Sumedi, jumlah anggaran tidak banyak, tetapi karena hampir setiap hari dilakukan oleh polisi, sehingga jumlahnya menjadi banyak. OTT yang dilakukan oleh Polri sifatnya spontan, berbeda dengan OTT yang dilakukan oleh KPK, yang dilakukan dengan penyadapan terlebih dahulu. Terkait dengan ketentuan tertangkap tangan, KUHAP harus tegas mengatur apa kriteria atau syarat tertangkap tangan. ${ }^{55}$

Sementara itu, OTT yang telah dilakukan oleh Polda Jatim selama pembentukan Saber Pungli, yaitu sebanyak 72 kasus korupsi se-Jawa Timur, merupakan kedua terbanyak setelah Jawa Barat. OTT merupakan istilah kegiatan “operasi”. Namun, OTT yang dilakukan oleh Polri pada umumnya jumlahnya tidak seberapa. Yang terbesar terkait OTT Alokasi Dana Desa tahun 2015 sebesar Rp.2 milyar. Sedangkan kasus korupsi yang ditangani oleh Polda D.I. Yogyakarta tidak banyak jumlahnya karena Yogyakarta merupakan salah satu daerah pilot project KPK. Target lima kasus korupsi yang ditangani oleh Polda dalam satu tahun, ditambah target satu kasus korupsi yang ditangani oleh Polres (lima Polres) dalam satu tahun, tahun lalu tercapai. ${ }^{56}$

Penyidik Tindak Pidana Korupsi Polda D.I. Yogyakarta (Iptu Karno Anggoro) mengatakan dalam hal tertangkap tangan tidak perlu administrasi, seperti surat izin. Istilah OTT adalah sebuah proses dengan teknologi, diikuti dengan kegiatan-kegiatan, seperti pembuntutan. Kepolisian tidak mempunyai kewenangan penyadapan seperti KPK, hanya menangani kasus secara konvensional berdasarkan laporan masyarakat, dan jumlahnya kecil, seperti dalam kasus pungli untuk pengurusan di imigrasi,

\footnotetext{
55 Wawancara dengan Sumedi dilakukan pada 18 April 2017.

56 Wawancara dengan Iptu Anggoro dilakukan pada 19 April 2017
}

tidak sampai Rp1 juta. ${ }^{57}$ Untuk mempersiapkan OTT, Polri melakukan pengamatan dengan membutuhkan waktu sampai 4 bulan. ${ }^{58}$

OTT yang dilakukan oleh Polri karena adanya Kebijakan Pemerintah, menindaklanjuti OTT terhadap Dinas Perhubungan terkait pengurusan izin. Jika dibandingkan dengan OTT yang dilakukan oleh KPK, Polri tidak mempunyai kewenangan penyadapan. Selain itu, fasilitas, anggaran, gaji polisi jauh lebih rendah dibandingkan dengan penyidik yang ditempatkan di KPK. Kesulitan yang dihadapi oleh Polri antara lain sarana prasarana yang tidak memadai dan teknik penyidikan yang dilakukan secara manual, sehingga harus mempunyai banyak jaringan sebagai informan yang identitasnya dirahasiakan. Sebenarnya proses OTT mengacu ke KUHAP dan UU Tipikor, berdasarkan laporan kemudian dilakukan penyelidikan.

Di Kejaksaan Tinggi (Kejati) D.I. Yogyakarta belum ada penyidikan perkara korupsi dari hasil tangkap tangan. Namun, ada satu perkara penuntutan perkara korupsi (imigrasi) dari hasil tangkap tangan Tim Saber Pungli. Demikian pula di Kejati Jawa Timur, sejak Saber Pungli dibentuk pada akhir tahun 2016 belum pernah ada kasus korupsi dari hasil OTT. Saber Pungli bekerja tergantung pada informan yang melaporkan adanya dugaan korupsi. Hal ini berbeda dengan KPK, yang melakukan OTT didahului dengan penyadapan. Namun, sebenarnya Kejaksaan juga mempunyai alat sadap, tetapi biasanya digunakan oleh tim khusus di Kejaksaan untuk mencari DPO-DPO. ${ }^{59}$

Kejaksaan merasa kesulitan dalam pelaksanaan tertangkap tangan dalam proses penyelidikan karena Kejaksaan tidak diberi wewenang melakukan penyadapan. Semua prosedur penanganan perkara tetap harus mengacu pada KUHAP. Tertangkap tangan dilakukan karena lebih mudah pembuktiannya. Pemberkasannya tetap sama prosedurnya

\footnotetext{
57 Wawancara dengan Iptu Anggoro dilakukan pada 19 April 2017

58 Wawancara dengan Kompol Joes Indra Lana Wira, Penyidik Tipikor Polda Jawa Timur, 16 Mei 2017.

59 Wawancara dengan Trimo, Kasi Penyidikan Kejaksaan Tinggi Jawa Timur, dilakukan pada 16 Mei 2017.
} 
sebagaimana diatur dalam KUHAP, namun harus lebih cepat karena pelaku OTT ditahan. Orang yang terkena OTT biasanya terbukti melakukan korupsi. ${ }^{60}$

Berbeda dengan informasi yang disampaikan oleh Jaksa dari Kejati Jawa Timur yang mengatakan belum pernah menangani kasus korupsi dari hasil OTT. Posma Ramos Sitompul (Advokat) ${ }^{61}$ menyebutkan, OTT pernah dilakukan oleh Kejati Jawa Timur terhadap Ahmad Fauzi (Jaksa), yang diduga menerima suap terkait kasus yang sedang ditangani dengan terdakwa Lurah Sumenep. OTT dilakukan berdasarkan laporan dari seseorang yang identitasnya dirahasiakan. Orang yang memberikan laporan bisa saja orang yang tidak suka atau lawan politik dari orang yang dilaporkan. OTT dapat disalahgunakan dan berakibat sangat buruk terhadap orang yang ditangkap dan keluarganya karena pelapor dirahasiakan, dan alat bukti yang minim. ${ }^{62}$

OTT yang didasarkan pada laporan memiliki kelemahan. Posma Ramos Sitompul, mengatakan OTT yang dilakukan berdasarkan laporan dengan alat bukti minim sangat merugikan pelaku yang terkena OTT karena yang bersangkutan langsung ditahan, sulit untuk melakukan pembelaan, padahal belum tentu bersalah. Oleh karena itu, OTT hendaknya dilakukan dengan bukti permulaan yang cukup dan dilakukan oleh para penyidik yang terpilih, sehingga pelaksanaannya tidak berdampak buruk terhadap orang yang ditangkap dan keluarganya. ${ }^{63}$

60 Wawancara dengan Azwar (Aspidsus), Ashari (Kasi Pidsus), dan Deri (Jaksa Fungsional) Kejaksaan Tinggi Provinsi D.I. Yogyakarta, dilakukan pada 20 April 2017.

61 Saat ini sedang menangani kasus Kepala Desa Kalimook Sumenep, yang telah divonis 6 (enam) tahun pidana penjara dan denda Rp6 miliar dalam kasus tanah kas desa, yang dianggap menimbulkan kerugian negara sebesar Rp6,4 miliar. Kasus tersebut saat ini dalam tahap pemeriksaan di tingkat kasasi.

62 Wawancara dengan Posma Ramos Sitompul dilakukan di Surabaya, 16 Mei 2017.

63 Advokat yang mendampingi Lurah Sumenep yang telah divonis 6 tahun penjara dan denda Rp6 miliar, dalam kasus tanah kas desa yang dianggap telah menimbulkan kerugian negara sebesar Rp6,4 miliar. Jaksa Penuntut Umum, Ahmad Fauzi, yang menangani kasus Lurah Sumenep,
Didik Endro Purwoleksono ${ }^{64}$ juga menyebutkan, bahwa OTT yang dilakukan oleh Polri dalam kasus Pungli telah sesuai dengan KUHAP. OTT yang dilakukan oleh aparat penegak hukum dapat mengurangi tindak pidana korupsi. Memang perlu penelitian yang lebih mendalam tentang hal ini, namun dengan merujuk pada banyaknya OTT, dapat dilihat:

a. tindak pidana korupsi merambah semua lini kehidupan di pelayanan publik oleh aparatur; b. sekarang masyarakat sudah banyak yang merasa tidak dipersulit untuk mengurus sesuatu atau berhubungan dengan aparatur; c. aparatur sekarang "agak" merasa ketakutan melakukan pungli.

OTT yang dilakukan oleh Polri untuk pemberantasan pungli, pada prinsipnya prosesnya sama dengan yang dilakukan oleh KPK, pasalnya sama karena akhirnya dianggap menerima gratifikasi atau suap. Namun demikian, melihat kinerja KPK, seringkali OTT dilakukan setelah dilakukan penyadapan terhadap "calon tersangka" tipikor. Dalam mengoptimalkan pemberantasan tipikor, Didik Endro Purwoleksono mengatakan semua penyidik perlu diberi kewenangan penyadapan dalam menangani tipikor. Penyidik yang dimaksud adalah Penyidik Polri; Penyidik Kejaksaan yang khusus menangani tindak pidana korupsi; dan Penyidik KPK. Hal ini karena tipikor mempunyai karakteristik lex spesialis (KUHP genus), extra ordinary crime, transnational crime, sistematically crime, organized crime, crime no victimization, white collar crime, corporate crime, yang dikenai pidana kumulatif yaitu pidana penjara dan denda; pidana minimum; pidana pembayaran uang pengganti; dan pidana pencabutan hak tertentu. ${ }^{65}$

Pendapat Didik tersebut sesuai dengan pendapat aparat penegak hukum, seperti

terkena OTT karena diduga menerima suap terkait kasus yang sedang ditangani dengan terdakwa Lurah Sumenep tersebut, dari Abdul Manaf. Wawancara dengan Posma Ramos Sitompul dilakukan pada 18 Mei 2017.

64 Wawancara dengan Didik Endro Purwoleksono dilakukan di Kampus Universitas Airlangga, pada 17 Mei 2017. 65 Ibid. 
Kejaksaan di Yogyakarta ${ }^{66}$ dan Jawa Timur ${ }^{67}$, sebagaimana telah disebutkan sebelumnya. Hakim Ad Hoc Pengadilan Tipikor di Surabaya (Jawa Timur), Agus Yunianto juga mengatakan hal yang sama. Agus mengatakan, dalam praktik hukum, pembuktian dari kasus OTT lebih mudah. ${ }^{68}$

Berdasarkan uraian sebelumnya, kewenangan penyadapan perlu diberikan kepada kepolisian dan kejaksaan, tetapi dengan ketentuan yang ketat. Untuk itu, ketentuan kewenangan penyadapan perlu segera diatur dalam undang-undang, sebagaimana amanat Putusan MK No. 5/PUU-VIII/2010. Dalam pertimbangannya, MK mengutip putusan MK sebelumnya, tertanggal 19 Desember 2006 dan putusan tertanggal 30 Maret 2004, yang menyatakan bahwa pembatasan penyadapan harus diatur dengan undang-undang guna menghindari penyalahgunaan wewenang yang melanggar hak asasi manusia. Selain itu, persyaratan tertangkap tangan dalam KUHAP harus dipertegas kriteria dan syaratnya, serta kapan waktu yang dimaksud pada frasa "setelah terjadinya", agar tidak tergantung pada penafsiran aparat.

Apabila mengacu pada model hukum acara pidana dari Herbert L. Packer, penanganan tipikor dengan OTT sesuai dengan CCM. Hal tersebut didasarkan pada OTT merupakan tindakan represif terhadap tipikor, yang ditujukan pada efisiensi penegakan hukum. Untuk efisiensi, penyidik tipikor menerapkan asas praduga bersalah. Penegakan hukum dilaksanakan dengan prinsip cepat dan tuntas.

\section{PENUTUP}

Dalam pemberantasan tindak pidana korupsi, KPK menggunakan istilah operasi tangkap tangan (OTT) terhadap pelaku yang ditangkap tangan dengan atau tanpa barang

\footnotetext{
66 Wawancara dengan Azwar (Aspidsus), Ashari (Kasi Pidsus), dan Deri (Jaksa Fungsional) Kejaksaan Tinggi Provinsi D.I. Yogyakarta, op.cit.

67 Wawancara dengan Trimo, Kasi Penyidikan Kejaksaan Tinggi Jawa Timur, Op.Cit.

68 Wawancara dengan Hakim Ad Hoc Pengadilan Tipikor Surabaya, Agus Yunianto, dilakukan pada 17 Mei 2017.
}

bukti yang dibawanya pada saat itu. Istilah OTT tidak disebut dalam KUHAP dan UU Tipikor, serta UU KPK. KUHAP sebagai ketentuan hukum acara pidana mengatur tertangkap tangan, yaitu tertangkapnya seseorang pada waktu sedang melakukan tindak pidana, atau dengan segera sesudah beberapa saat tindak pidana itu dilakukan, atau sesaat kemudian diserukan oleh khalayak ramai sebagai orang yang melakukannya, atau apabila sesaat kemudian padanya ditemukan benda yang diduga keras telah dipergunakan untuk melakukan tindak pidana itu yang menunjukkan bahwa ia adalah pelakunya atau turut melakukan atau membantu melakukan tindak pidana itu. Syarat tertangkap tangan tersebut bersifat alternatif, artinya apabila salah satu terpenuhi dapat dikategorikan sebagai tertangkap tangan. Pada kenyataannya ketentuan ini biasanya terjadi dalam tindak pidana umum. Berdasarkan hasil penelitian, OTT yang dilakukan oleh KPK tidak dianggap melanggar KUHAP, tetapi hanya salah menggunakan istilah.

KPK banyak melakukan OTT, terutama dalam dua tahun terakhir, 2016 dan 2017. OTT yang dilakukan oleh KPK didahului dengan penyadapan, kewenangan yang dimiliki berdasarkan undang-undang. Sementara itu, Satgas Saber Pungli yang beranggotakan antara lain Polri dan Kejaksaan, tidak mempunyai kewenangan penyadapan dalam menangani kasus korupsi. Berdasarkan hasil penelitian, untuk harmonisasi, kewenangan penyadapan perlu diberikan kepada penyidik Polri dan Kejaksaan yang menangani kasus korupsi. Mekanisme dan prosedur penyadapan perlu segera diatur dalam undang-undang, sebagaimana amanat Putusan MK No. 5/PUU. VIII/2010. Selain itu, persyaratan tertangkap tangan dalam KUHAP harus dipertegas kriteria dan syaratnya, serta kapan waktu yang dimaksud pada frasa "sesudah beberapa saat" dan "setelah terjadinya", agar tidak tergantung pada penafsiran aparat. 


\section{DAFTAR PUSTAKA}

\section{Jurnal}

Akbar, Muhammad Rizal. "Kebijakan KPK dalam Penanggulangan Tindak Pidana Korupsi melalui Operasi Tangkap Tangan”. Jurnal. Fakultas Hukum Universitas Lampung. 2016.

Asyari, Fatimah. "Operasi Tangkap Tangan di Pusat dan Daerah untuk Meraih WTP Terkait Masalah Pelanggaran Hukum". Jurnal Legalitas. Vol. 2 No. 1. Juni 2017.

Edwira, Muhammad Randa. "Upaya Penanggulangan Tindak Pidana Pungutan Liar oleh Satuan Tugas Sapu Bersih (Studi Kasus di Wilayah Hukum Bandar Lampung)". Jumal Skripsi. Fakultas Hukum Universitas Lampung. 2018.

Gautama, Mohammad Isa. "Primordialisme Semu Versus Gerakan Antikorupsi (Studi Kritis Pemberitaan Tangkap tangan Irman Gusman di Media Daring Sumatera Barat dan Nasional)". Prosiding Magister Ilmu Komunikasi. Jurnal FISIP Unila. 2017.

Jh. Kumendong, Wempie. "Kajian Hukum tentang Satuan Tugas Sapu Bersih Pungutan Liar Menurut Peraturan Presiden Republik Indonesia No. 87 Tahun 2016". Lex Privatum Vol. V/No. 2/ Maret-April/ 2017.

Suharyo. "Optimalisasi Pemberantasan Korupsi dalam Era Desentralisasi di Indonesia". Jurnal Rechtsvinding. Vol. 3. No. 3. Desember 2014.

Sukri, Al, dan Chelsy Yesicha. "Analisis Framing Berita Penangkapan Gubernur Riau Annas Maamun di Surat Kabar Riau Pos dan Tribun Pekanbaru". Jumal Komunikasi Global. Volume 6. Nomor 2. 2017.

\section{Buku}

Danil, Elwi. Korupsi Konsep, Tindak Pidana, dan Pemberantasannya. Jakarta: PT RajaGrafindo Persada. 2012.
Hamzah, Fahri. "Sistematika Pemberantasan Korupsi”. Makalah. Seminar Nasional dengan tema "Pemetaan Korupsidi Lembaga Eksekutif, Legislatif, dan Yudikatif: Strategi Pencegahan dan Penindakannya". Pusat Penelitian Badan Keahlian DPR RI. 30 Maret 2017.

Moeljatno, Hukum Acara Pidana, Yogyakarta: Penerbit Universitas Gajah Mada, 1981.

Pangaribuan, Aristo M.A., Arsa Mufti, dan Ichsan Zikry. Pengantar Hukum Acara Pidana di Indonesia. Jakarta: Rajawali Pers. 2017.

Ramelan. Hukum Acara Pidana: Teori dan Implementasi. Jakarta: Sumber Ilmu Jaya. 2006.

Rohim. Modus Operandi Tindak Pidana Korupsi. Jakarta: Pena Multi Media. 2008.

\section{Makalah dan Laporan Penelitian}

Bawono, Bambang Tri. "Analisa Yuridis terhadap Tindakan Tangkap Tangan Terhadap Pelaku Dugaan Tindak Pidana Gratifikasi”. Laporan Penelitian, Fakultas Hukum Universitas Islam Sultan Agung. Semarang. 2013.

Nola, Luthvi Febryka. "Operasi Tangkap Tangan oleh KPK". Info Singkat. Vol. V No. 24/II/P3DI/Desember 2013. Pusat Pengkajian Pengolahan Data dan Informasi Setjen DPR RI.

\section{Pustaka dalam Jaringan dan Surat Kabar}

"KPK: 17 OTT di 2016 Terbanyak Sepanjang Sejarah", 9 Januari 2017, https://news. detik.com/berita/d-3391210/kpk-17-ott-di2016-terbanyak-sepanjang-sejarah, diakses tanggal 12 Mei 2018.

"Kasus Suap Kapal, Ini Kronologi Operasi Tangkap Tangan KPK", 1 April 2017, https://nasional.tempo.co/read/861572/ kasus-suap-kapal-ini-kronologi-operasitangkap-tangan-kpk, diakses tanggal 1 April 2017. 
"Pencalonan Tidak Berdasarkan Integritas”, Suara Pembaruan, 27 Desember 2017.

"Penyelidik KPK Ungkap Cerita OTT Irman Gusman", 4 Januari 2017, https://news. detik.com/berita/d-3387547/penyelidikkpk-ungkap-cerita-ott-irman-gusman, diakses tanggal 20 Februari 2017.

"Kronologis Penangkapan Akil Mochtar", 3 Oktober 2013, http://www.republika.co.id/ berita/nasional/hukum/13/10/03/mu3hdykronologis-penangkapan-akil-mochtar, diakses tanggal 20 Februari 2017.

"KPK: Penyuap Patrialis Pernah Diperiksa Kasus Impor Daging Sapi”, 27 Januari 2017, http://news.liputan6.com/read/2838364/ kpk-penyuap-patrialis-pernah-diperiksakasus-impor-daging-sapi, diakses tanggal 20 Februari 2017.

"Tertangkap Tangan Pertama Polisi dan Kekhawatiran Pencitraan", 12 Oktober 2016, http://www.cnnindonesia.com/nasio nal/20161012090723-12-164914/tangkaptangan-pertama-polisi-dan-kekhawatiranpencitraan/, diakses tanggal 10 Maret 2017.

"Polda Metro Jaya: OTT Pungli Bukan Hal Baru di Kepolisian”, 18 Oktober 2016, http:// metro.news.viva.co.id/news/read/836194polda-metro-jaya-ott-pungli-bukan-halbaru-di-kepolisian, diakses tanggal 2 Maret 2017.

"Satgas Saber Pungli Lakukan 71 OTT Sepanjang 2016", 6 Januari 2017, http:// news.liputan6.com/read/2820153/timsatgas-saber-pungli-lakukan-71-ottsepanjang-2016, diakses tanggal 2 Maret 2017.

"Laica Marzuki Jadi Saksi Ahli IG", 28 Oktober 2016, http:/harianhaluan.com/news/detail/ 61394/istilah-ott-kacaukan-hukum-acara, diakses tanggal 2 Februari 2017.
"Memahami Istilah Operasi Tangkap Tangan di Kasus Patrialis Akbar", 30 Januari 2017, https:/news.detik.com/berita/d-3409476/ memahami-istilah-operasi-tangkap-tangandi-kasus-patrialis-akbar, diakses tanggal 20 Februari 2017.

"Menurut Jaksa Agung, OTT Kerap Bikin Gaduh", 11 September 2017, https:// nasional.kompas.com/read/2017/09/11/ 15551721/menurut-jaksa-agung-ott-kerapbikin-gaduh, diakses tanggal 13 Maret 2018.

"Operasi Tangkap Tangan oleh KPK", 1 Februari 2017, https://www.nyatnyut. com/2017/02/01/operasi-tangkap-tanganoleh-kpk/, diakses tanggal 14 Mei 2017.

"Modus Kian Canggih", Kompas, 20 Januari 2018.

"Ini Daftar Lengkap 19 OTT KPK Sepanjang 2017", 1 Januari 2018, http://nasional. republika.co.id/berita/nasional/ hukum/18/01/01/p1vv1h409-ini-daftarlengkap-19-ott-kpk-sepanjang-2017, diakses tanggal 22 Maret 2018.

"Sejak Dibentuk, Saber Pungli Lakukan 856 OTT", 19 Juni 2017, https://nasional. kompas.com/read/2017/06/19/19074671/ sejak.dibentuk.saber.pungli.lakukan.856. ott. diakses tanggal 23 Maret 2018.

\section{Lain-lain}

Komite Pemberantasan Korupsi, Laporan Tahunan KPK Tahun 2016.

Komite Pemberantasan Korupsi, "Capaian dan Kinerja KPK di Tahun 2017". Siaran Pers disampaikan oleh Pimpinan KPK, 27 Desember 2017. 